\title{
A NEW SPECIES OF RUELLIA (ACANTHACEAE) FROM PANAMA
}

\author{
Dieter C. Wasshausen \\ Smithsonian Institution, Washington, D.C. 20560
}

RUELLIA COLONENSIS Wasshausen, sp. nov.

Herba, caulibus quadrangularibus, angulis acutis, pilosis et subtomentosis; lamina follorum ovata vel oblongo-ovata, acuminata, basi cuneata, aliquanto firma, undulata vel crenato-serrata, supra glabra vel pilos paucos ferens, subtus parce vel aliquanto dense pilosa, costa et venis et venulis prominentibus; petioli pilosi, pilis appressis; spicae terminales et subterminales, floribus in fasciculis confluentibus, bracteis et bracteolis prominentibus, glandulosis-pilosis et ciliolatis; bracteae fasciculas subtendentes foliaceae; bracteolae oblongae, subacutae vel subobtusae; calycis segmenta lanceolata, ciliata; corolla rubra, minute pubescens, tubo hypocrateriformi, curvato, lobis suborbicularibus; stamina plus minusve inclusa, filamentis sursum glabris, basi puberuli, antheris oblongis.

Herb to $0.5 \mathrm{~m} \mathrm{high;} \mathrm{stems} \mathrm{quadrangular,} \mathrm{the} \mathrm{angles} \mathrm{sharp} \mathrm{or}$ the lower portions subquadrangular, pilose and subtomentose, the hairs appressed, brownish, to $1.5 \mathrm{~mm}$ long; leaf blades ovate to oblong-ovate, $13.5-20 \mathrm{~cm}$ long, $4.5-7.5 \mathrm{~cm}$ wide, acuminate, cuneate at base, rather firm, undulate or crenate-serrate, the upper surface glabrous or bearing a few scattered hairs, the lower surface sparingly to rather densely pilose, especially the costa and lateral veins (about 10 pairs), the hairs appressed to ascending, to $0.3 \mathrm{~mm}$ long, the venation prominent beneath, less so above, the cystoliths rather obscure; petioles $4-5 \mathrm{~cm}$ long, appressed-pilose, the hairs similar to those on the stem; flowers borne in fascicles, these sessile, confluent, forming terminal and sometimes subterminal spikes, these $12 \mathrm{~cm}$ long and $3 \mathrm{~cm}$ wide (without corollas), the bracts and bractlets conspicuous, moderately glandular-pilose and ciliate, the hairs to $1.25 \mathrm{~mm}$ long, ascending, the bracts subtending the fascicles leaflike, lanceolate, 2-3 cm long and 5-6 mm wide or the lowermost somewhat larger, long-acuminate, the bractlets oblong to oblanceolate, $1.2 \mathrm{~cm}$ long and $1.8-2 \mathrm{~mm}$ wide, subacute to subobtuse; calyx segments narrowly lanceolate, subequal, $16 \mathrm{~mm}$ long, $1.8-2 \mathrm{~mm}$ wide, gradually narrowed to a slender tip, the margins densely ciliate with spreading glandular hairs, the inner surface puberulous, the outer intermixed glandular-pilose and puberulous; corolla 5.5-6.5 cm long, bright red, minutely pubescent, the tube curved, $2.5 \mathrm{~mm}$ broad at base, narrowed above ovary to $2 \mathrm{~mm}$, thence gradually enlarged to about $11 \mathrm{~mm}$ at mouth, the $1 \mathrm{mb} 1.5$ $\mathrm{cm}$ broad, the lobes suborbicular, $3 \mathrm{~mm}$ in diameter; stamens reaching or slightly exceeding the mouth of the corolla, $18 \mathrm{~mm}$ long; filaments glabrous except toward the puberulous base, $15 \mathrm{~mm}$ long; anthers oblong, $5 \mathrm{~mm}$ long, $1.3 \mathrm{~mm}$ broad, rounded at 
both ends; pollen grains typical, 3-porate, spheroidal, $75 \mu$ in diameter, pores more or less circular, the reticulum homobrochate; style slightly exceeding the stamens in length, glabrous except at base, here puberulous; stigma lobes linear, unequal, one, the upper $1.5 \mathrm{~mm}$ long, the lower $2.5 \mathrm{~mm}$ long; capsule not seen.

Type. Dwyer \& Gentry 2371 (holotype US, isotype MO), Panama, Colon: Santa Rita Ridge, 30 Dec 1971. Distribution. Known only from the type locality. Ruellia colonensis is readily distinguished by the long, terminal spike, the conspicuous bracts and bractlets, and the long, bright red corolla. It is not very closely allied to any of the known species of Ruellia. 


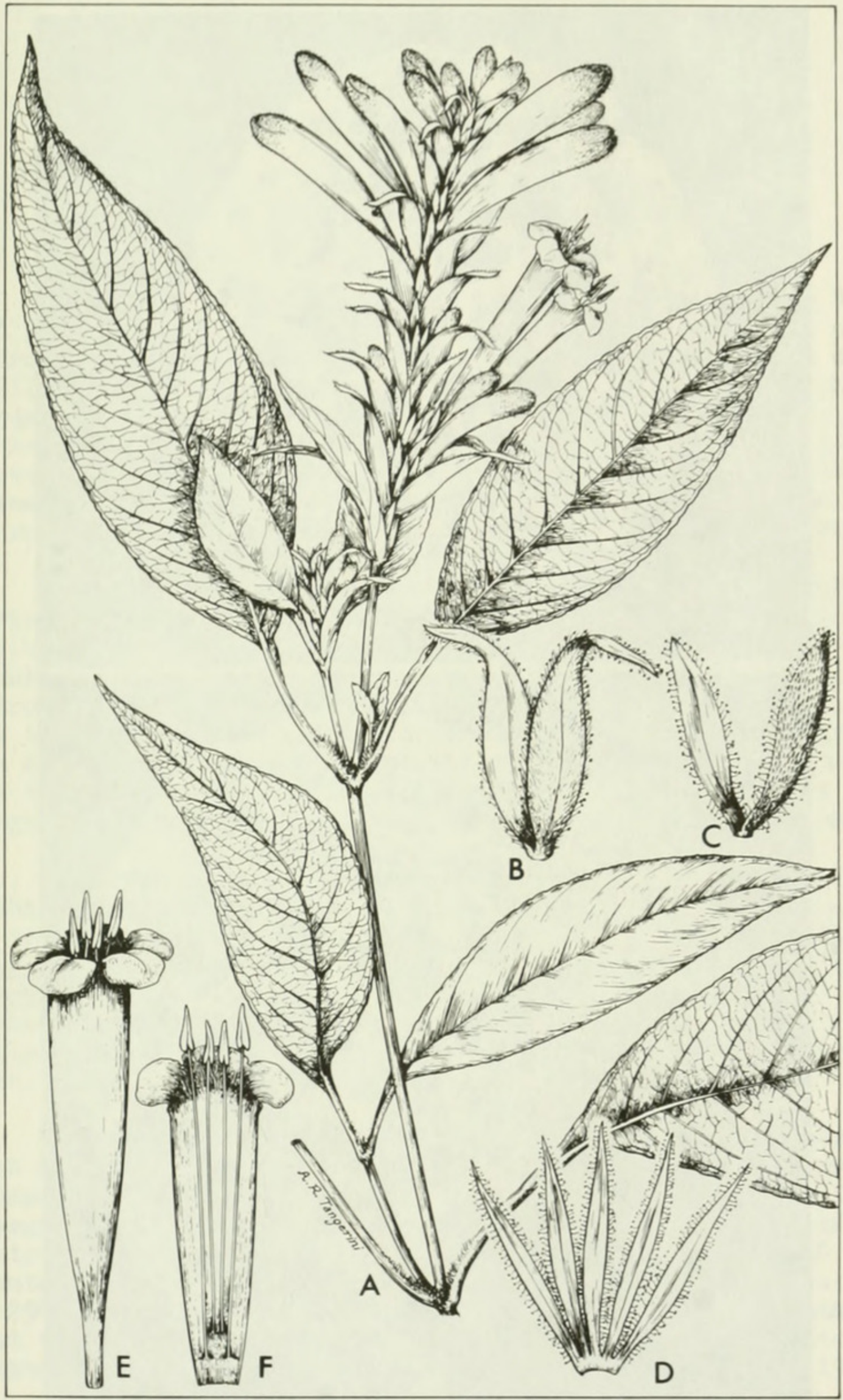

Ruellia colonensis Wasshausen: A, habit, $X \frac{1}{2}$; B, bracts, $\mathrm{X} 1 \frac{1}{2} ; \mathrm{C}$, bractlets, X $2 \frac{1}{2} ; \mathrm{D}$, calyx segments, X $2 \frac{1}{2} ; \mathrm{E}$, corolla, X 1; F, corolla expanded, X 1 . 
Vol. 33, no. 1
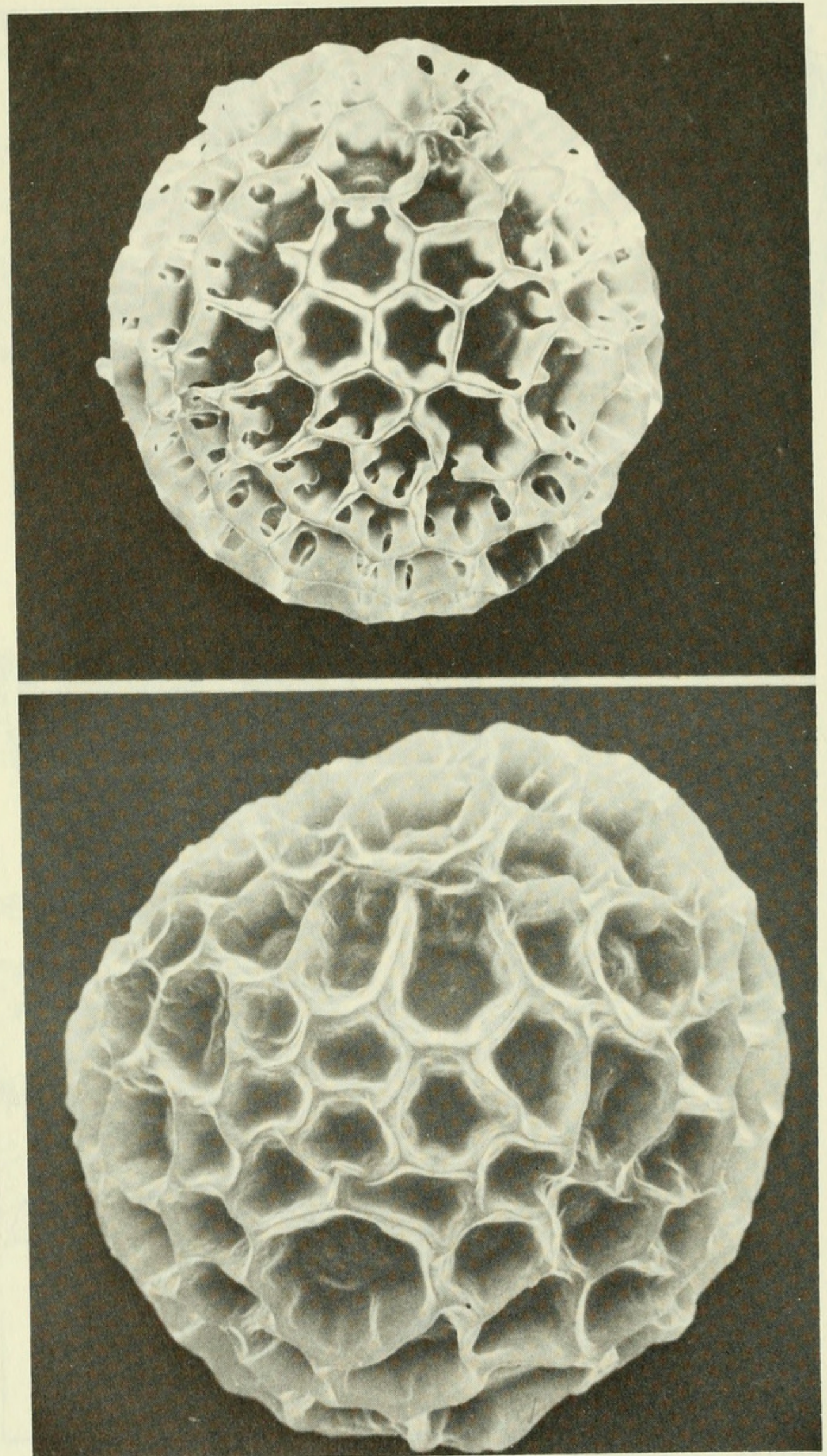

Spheroidal pollen grains of Ruellia colonensis Wasshausen (Dwyer \& Gentry 2371); above, X 750; below, X 1,000. 


\section{$2 \mathrm{BHL}$ Biodiversity Heritage Library}

Wasshausen, Dieter C. 1976. "A new species of Ruellia (Acanthaceae) from Panama." Phytologia 33, 59-62. https://doi.org/10.5962/bhl.part.16780.

View This Item Online: https://www.biodiversitylibrary.org/item/47086

DOI: https://doi.org/10.5962/bhl.part.16780

Permalink: https://www.biodiversitylibrary.org/partpdf/16780

\section{Holding Institution}

New York Botanical Garden, LuEsther T. Mertz Library

\section{Sponsored by}

The LuEsther T Mertz Library, the New York Botanical Garden

\section{Copyright \& Reuse}

Copyright Status: In copyright. Digitized with the permission of the rights holder.

Rights Holder: Phytologia

License: http://creativecommons.org/licenses/by-nc-sa/3.0/

Rights: https://biodiversitylibrary.org/permissions

This document was created from content at the Biodiversity Heritage Library, the world's largest open access digital library for biodiversity literature and archives. Visit BHL at https://www.biodiversitylibrary.org. 